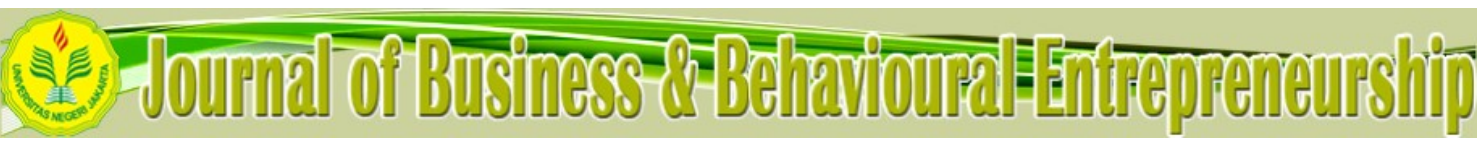

\title{
Career Development of Indonesian National Police: The Case Study Analysis of Police Grand Comissioner Rank
}

\author{
Mustafa Hari Kuncoro \\ Doctoral Program of HRM Department, Jakarta State University, Indonesia \\ Email: mustafahari_im12s3@mahasiswa.unj.ac.id \\ Billy Tunas \\ Doctorate Program Of Jakarta State University, Indonesia \\ Wibowo \\ Doctorate Program Of Jakarta State University, Indonesia
}

\begin{abstract}
It was important for Indonesian National Police organizations to be able to managed their human resources through good management by giving employees or members the opportunity to advance. Human resources in one organization had an important role of Indonesian National Police experiences a surplus of members with the position of Police Grand Commissioner. As of the beginning of 2019, this institution had around 1,400 members serving as middle officers. Most of these officers did not get any positions. The development system of the right police career pattern was able to provide direction for individual police officers to developed themselves. The purposed of this research was to analyzed case studies related to the career development of the Police Grand Commissioner ranked that took place at the Institution of Indonesian National Police. This research used a qualitative approach with a case study method. This study concluded that career development was an police's efforts to achieve a career plan. In this case, there were organizational efforts in the form of programs and activities to assisted the career development of Police Grand Commissioner personnel. Another important thing was related to education and training provided to Police Grand Commissioner personnel must be in accordance with the requirements needed, so that the quality improvement of Police Grand Commissioner personnel would be truly fulfilled and aimed to developing police competencies and careers in accordanced with the needs and challenges of Grand Commissioner Police personnel performance.
\end{abstract}

Keywords: Career, Career Development, Police, Indonesian National Police, Grand Commissioner Police

Received: 8 November 2019 ;

Accepted: 16 December 2019 ;

Publish; December 2019.

\section{How to Cite:}

Kuncoro, M.H., Tunas, B., \& Wibowo. (2019). Career Development of Indonesian National Police: The Case Study Analysis of Police Grand Comissioner Rank. Journal of Business and Behavioural Entrepreneurship, 3(2), 58-71. https://doi.org/10.21009/ JOBBE.003.2.04 


\section{INTRODUCTION}

In this era of changing Industrial Revolution 4.0 rapidly, the main challenges in guarding an organization so that it can continue to excel and survive in achieving its goals is how the organization can be more flexible and adaptive to face any changes that occur (Nurmadi, et. al., 2016:241). At the end of this decade, the flow of globalization which is supported by advances in information and communication technology has an impact on changes in the social, economic and political environment that is accelerating (Schlesinger, Nagi, \& Kremnitzer, 2017:72). According to Marnoch, Topping, \& Boyd (2014), along with the demands of this organizational change, the concepts of organizational change and development (organizational change and development) as part of organizational behavioral science (behavioral science) began to be developed because It was considered as one of the strategic change management approaches which is needed for every organization that has the desire to continue to survive, move forward and excel.

Indonesian National Police Reform began to be rolled out since the enactment of Law No. 2 of 2002 on Indonesian National Police to oversee the change from an institution based on command and militarism to an independent civilian based police institution and expected to be more professional in creating security and order for the community. Indonesian National Police is a large organization, whose existence is spread from the Police Headquarter level to the Police Sector level. Indonesian National Police has as many as 443,000 officers. Indonesian National Police is one of the government institutions that is implementing changes in national life order towards a democratic, safe, orderly, just and prosperous civil society. It is important for Indonesian National Police institutions to be able to manage their human resources through good management by giving employees or members the opportunity to advance.

Human resources in one organization has an important role. Success in an organization can be determined from the quality of the people in the organization. Human resources whose abilities, skills and skills have the desire to work actively in an effort to achieve optimal work results are important capital in a police unit (Sanders, 2003:316; Gunawan, et. al., 2016:320). Indonesian National Police Headquarters said that currently there are 400 officers with the rank of Police Grand Commissioner is not included in the Indonesian National Police structure. The reason for not having a position is because most of them have just graduated from education and have not a position yet or are still unemployed of structure. According to Police Brigadier General Dedi Prasetyo, Head of Public Relations Bureau of Civil Relations of Indonesian National Police, there are currently 1,400 officers in the composition of officers. Of the 1,400 members of the National Police Commission with the rank of the Kombes, there are 400 Kombes who have just finished their education and have not been accommodated.

Indonesian National Police experiences a surplus of members with the position of Police Grand Commissioner. In early of 2019, Indonesian the National Police had around 1,400 officers serving as middle rank officers. Most of the officers did not get outside structural positions. However, the Indonesian National Police must implement a merit system and have not increase the rank of its members just because of the length of its term of office. The large number of middle-ranking officers (Police Grand Commissioner) who become policy analysts is not only show the phenomenon of weak career development management within the Indonesian National Police, but also have led to inefficiency and ineffectiveness in human resource management clearly. In fact, Gunawan, et. al. (2016:323) said that these conditions had led to psychological condi-

* Career Development of Indonesian National Police: The Case Study Analysis of Police Grand Comissioner Rank. 
tions that were less conducive to the Police Grand Commissioner who were stranded or forced to become a policy analyst, from feelings of disappointment, demotivation to stress.

The condition is uncertainly without cause, but there are obstacles that prevent it, so it is necessary to find appropriate solutions and strategies to anticipate it (Jeffrey \& Soleman, 2017:110; Nurmadi, et. al., 2016:250). Career development has a future existence that depends on human resources because it must carry out career guidance for workers that is carried out in a planned and sustainable manner every year (Dik, Sargent, \& Steger, 2008:27). Junjunan \& Suwanda (2019:97) stated that career development has a very large existence for an organization in the Field of Government because career development is a benchmark for individuals in conducting career coaching. Career development as a human resource management activity basically has a goal to be able to improve and improve the effectiveness of the work carried out by workers so that they are increasingly able to provide the best contribution in realizing organizational goals (Patrick \& Kumar, 2011:25).

In 2016, this rank control was carried out with the Regulation of the Head of the Republic of Indonesia National Police Number 3 of 2016 concerning the Administration of Members of the Republic of Indonesia National Police. The term of office of an officer who wants to become a Police Commissioner is at least 21 years, two years longer than before. To meet the first -level officers in the Republic of Indonesia National Police, there are four pathways, namely Transfer of Education, Police Inspector School, Police Source Inspector School, and Police Academy. From the Alih Golongan Education school, members who graduate only have a term of service of eight years until retirement with the final rank of Adjunct Police Commissioner.

For the Police Inspector School, the official service term reaches 14 years with the maximum rank of Adjunct Senior Commissioner of Police. For Undergraduate Police Inspector Schools, they work in the fields of scholarship such as medicine, psychologists, and the like without limitations. As for the Police Academy, they can reach up to the level of the Senior Commissioner of Police (Middle Officers) to General (High Officers). Therefore, to prevent a build-up at the level of the Police Chief Commissioner, it is necessary to limit the Police Academy graduates who can reach the rank of Chief Commissioner. Each year the number of graduate officers and the Police Inspector School is above 3,000, while the Police Academy has only 250 people and the Police Inspector School has 50 people.

According to Prenzler \& Sinclair (2013:115), the system of developing the right police's career pattern is able to provide direction for individual police officers to develop themselves. An appropriate career pattern development system can accelerate the achievement of organizational goals (Junjunan \& Suwanda (2019:100). Effective career development is a living process and a process that develops and changes following increasingly flexible organizations (Wilson, 2014:79). Career development is not something that is static and permanent, and therefore must be studied continuously and developed continuously (Campbell \& Armstrong, 2013:242).

Indonesian National Police should be able to play a role in providing police career and competency development facilities in accordance with the principles of human resource management, such as: (1) job requirements, (2) career paths and pathways, (3) employee competency development, (4) employee performance management, (5) career development counseling, (6) assessment and evaluation, and (7) human resource management information systems. The purpose of this research is to analyze case studies related to the career development of the Police Grand Commissioner that took place at the Institution of Indonesian National Police.

* Career Development of Indonesian National Police: The Case Study Analysis of Police Grand Comissioner Rank.

* $\quad$ https://doi.org/10.21009/JOBBE.003.2.04 


\section{LITERATURE REVIEW}

\section{Human Resource Management : Description and Role Framework}

Filstad \& Gottschalk (2011:488) said that human resource management refers to the policies and practices involved in carrying out 'people' or aspects of human resources from management positions, including, recruitment, screening, training, appreciation, and assessment. Resource management is the design of formal systems in an organization to ensure effective use of employee knowledge, skills, abilities, and other characteristics to achieve organizational goals (Campbell \& Armstrong, 2013:250). Resource management concerns the recruitment, selection, training and development, compensation and benefits, retention, evaluation, and promotion of employees, and employee relations with management in an organization (Gunawan, et. al., 2016:329) Resource management is a function that displayed the organization in facilitating employees to be more effective in achieving organizational and individual goals (Marnoch, Topping, \& Boyd, 2014:311).

Resource management is defined as a strategic and coherent approach to the management of the most valuable assets in an organization that is the people who work on it individually and collectively who contribute to the achievement of its objectives. Human resource management is built when the organization systematically understands, creates, coordinates, aligns (maintains) and integrates all policies and practices (Ivancevich, Konopaske, \& Matteson, 2013). Resource management in the sense of a broader management function and specific approach can be understood as a comprehensive set of managerial activities and the tasks concerned by developing and maintaining quality human resources that can contribute to organizational effectiveness (Banfield \& Kay in Kathimba \& Anyieni, 2018:160). This model is summarized in the following chart (Banfield \& Kay in Kathimba \& Anyieni, 2018:161):

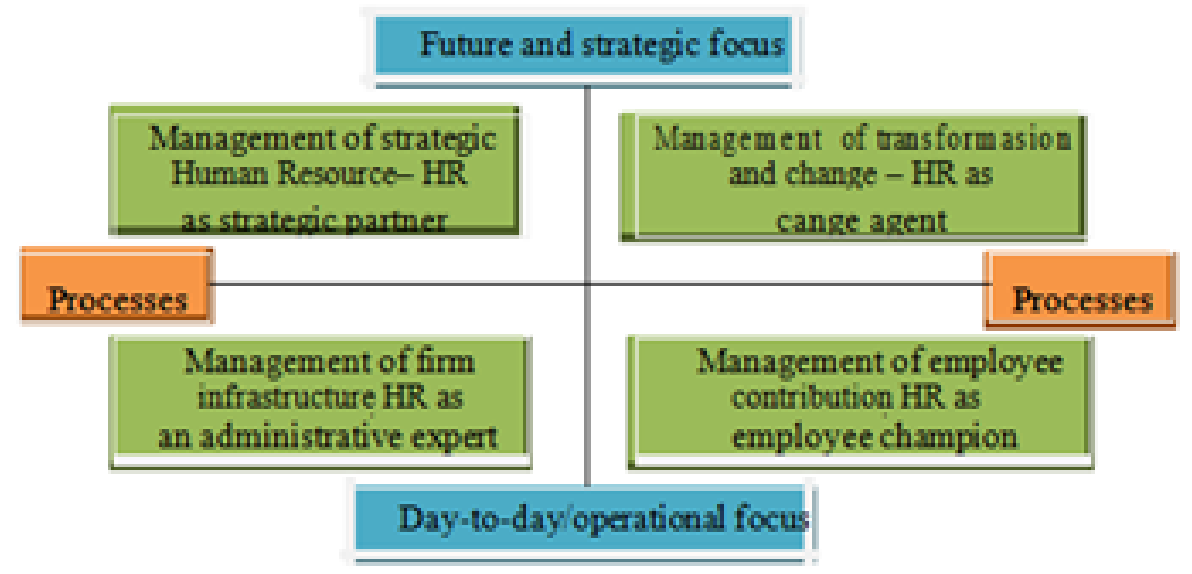

Figure 1. Framework for Understanding the Role of Human Resources (Source: Banfield \& Kay dalam Kathimba \& Anyieni, 2018:161)

\section{Organizational Behavor Theory : The Principle and Scope}

Organizational behavior theory basically bases its study on behavioral science itself (the root of psychology), which was developed with its focus on human behavior in organizations (Wibowo, 2015). Individual behavior is a reaction that is owned by an individual to everything that is seen, felt, and understood to further form in actions and attitudes (Griffin \& Moorhead, 2014). In the context of behavioral science it is explained that each person has different views in assessing and understanding each situa-

* Career Development of Indonesian National Police: The Case Study Analysis of Police Grand Comissioner Rank.

* $\quad$ https://doi.org/10.21009/JOBBE.003.2.04 
tion, especially if it is set forth in the background (background) that he had lived. This understanding is in accordance with the formula Kelly explains that organizational behavior in which there are interactions and relationships between organizations on the one hand and individual behavior on the other hand (Campbell \& Armstrong, 2013:244).

Colquitt in Jeffrey \& Soleman (2017:109), organizational behavior is a study used to understand, explain and improve the attitudes and behavior of individuals and groups in organizations. According to Robbins in Robinson (2013: 4), organizational behavior is a field of study that invests the influence of individuals, groups and structures on behavior in organizations for the purpose of applying knowledge to increase organizational effectiveness. Organizational behavior studies three determinants of behavior in organizations, namely individuals, groups, and structures (Filstad \& Gottschalk, 2011:490). Organizational behavior also applies knowledge gained about individuals, groups and the effects of structure on behavior to make organizations work more effectively (Sanders, 2003:323).

\section{Career Development : Definition, Planning, Path, and Strategy}

According to Patrick \& Kumar (2011:25), career is the scope of work which is what people do for their lives. Careers related to one's life, therefore there is a need for career planning (Wibowo, 2015). A similar opinion was conveyed by Wilson (2012:329) that a career is a scope and pursuit of work that includes what people do to make a living. An understanding of career development can be explained by Patton \& McMahon in Junjunan \& Suwanda (2019:101) that career development is the total constellation of psychological, sociological, educational, physical, economic and chance factors that combine to shape the career of an individual over the individual life span. Career development is a total constellation of psychological, sociological, educational, physical, economic and opportunity factors that combine to shape an individual's career over the life span (Marnoch, Topping, \& Boyd, 2014:312). Mondy in Trofymowych (2007:422) argues that career development is a formal approach taken by the organization to ensure that people with the proper qualifications and experiences are available when needed.

According to White (2008:123), career planning is a sequence of activities related to the life of an individual and his work or sequential patterns of work. On the other hand, Malthis \& Jackson in Wibowo (2015) revealed that although career goals and perspectives in career planning may differ for institutions / organizations and employees, there are three problems for both, namely stable career periods, technical workers and professional workers, and dual career. Flippo in Griffin \& Moorhead (2014) identified several aspects in the steps of developing career development, as follows: (1) Career need assessment; (2) Career opportunities; (3) Need opportunity alignment. The study of the stages of a career has found the needs and expectations in order to change individuals to move through the stages. Career stages are very important and are needed when someone wants to develop his career in an organization.

Career path is a pattern of work Sequence that employees must go through to achieve a career goal that is always ideal and normative (Dik, Sargent, \& Steger, 2008:28). Career development in an organization means connecting organizational needs with individual needs (Jeffrey \& Soleman, 2017:111). The stages can be described as shown in the following chart:

* $\quad$ Career Development of Indonesian National Police: The Case Study Analysis of Police Grand Comissioner Rank.

* $\quad$ https://doi.org/10.21009/JOBBE.003.2.04 


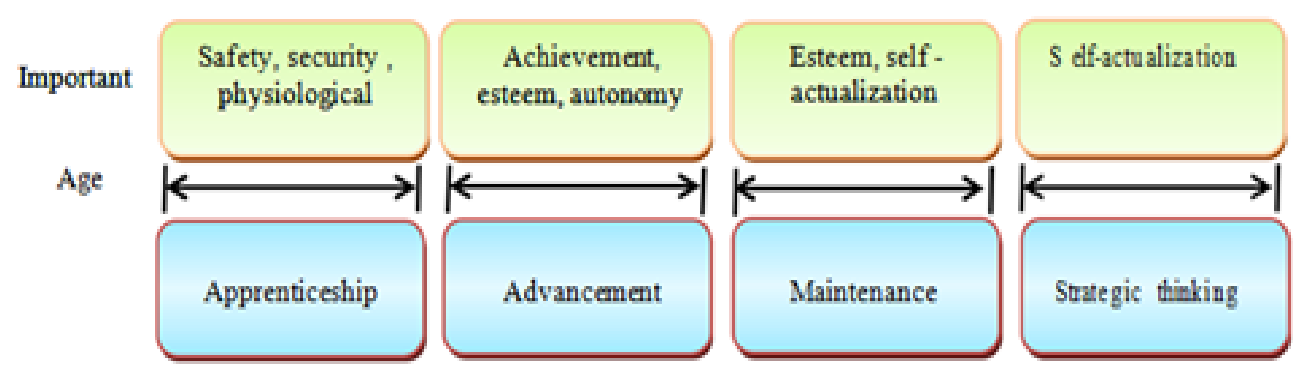

Figure 2. Career Path and Important Needs

(Source: Ivancevich, Konopaske, \& Matteson, 2013:436)

Ivancevich, Konopaske \& Matteson (2013) mentioned several activities in career development strategies, namely: (1) a policy of promoting from within wherever possible; (2) career routes enabling talented people to move from bottom to top of the organization, or laterally in the firm, as their development and job opportunities take them; (3) personal development planning as a major part of the performance management process, in order to develop each individual's knowledge and skills; (4) systems and processes to achieve sharing and development of knowledge (especially tacit) across the firm; (5) multi-disciplinary project teams with a shifting membership in order to offer development opportunities for as wide a range of employees as possible.

\section{National Indonesian Police : Laws and Functions}

Indonesian National Police is the National Police in Indonesia, which is directly responsible under the President. Indonesian National Police has police duties throughout Indonesia. According to Law No. 2 of 2002 concerning Indonesian National Police, the definition of Police is all matters relating to the functions and institutions of the police in accordance with statutory regulations (Sethi, 2013: 56). Duties, functions, and authority are carried out on the obligation to conduct intensive supervision and if necessary by coercion carried out by carrying out public obligations with the intermediaries of the court, and forcing the governed to carry out general obligations without court intermediaries (White \& Escobar, 2008:36) .

In connection with the duties and authorities of the police, this must be carried out properly so that the objectives of the police as set out in the articles are useful, the police law aims to ensure orderly and upholding the law and the establishment of public peace in the context of maintaining state security, the maintenance of the defense and security functions. the state, the achievement of national goals by upholding the function of human rights is accomplished (Wilson \& Heinonen, 2012:285).

\section{RESEARCH METHODOLOGY}

This study uses a qualitative approach and concentrates intensively on one particular object that studies it as a case. Case study data can be obtained from all parties concerned, in other words in this study collected from various sources (Sugiyono, 2014). According to Yin (2014), the case study method is a suitable strategy if the research question concerns "how" or "why", if the researcher has few opportunities to control the events being investigated, and if the focus of his

* Career Development of Indonesian National Police: The Case Study Analysis of Police Grand Comissioner Rank.

* $\quad$ https://doi.org/10.21009/JOBBE.003.2.04 
research lies in contemporary phenomena in the context of real life . Determination of informants in this study uses purposive techniques with certain considerations which constitute 7 people with the position of Police Grand Commissioner, among others as follows:

Table 1. Profile Identity of Informant

\begin{tabular}{|c|c|c|c|c|c|}
\hline Informant & & & & & Status \\
\hline Code & Age & Gemuer & C OSItion & & Pension) \\
\hline KBP-01 & 59 & Male & \begin{tabular}{|l} 
ANALIS KEBIJAKAN MADYA \\
ROLEMTALA SRENA POLRI
\end{tabular} & $\begin{array}{l}\text { Police Grand } \\
\text { Commissioner } \\
\end{array}$ & Active \\
\hline KBP-02 & 49 & Male & $\begin{array}{c}\text { ANALIS KEBIJAKAN MADYA } \\
\text { BIDANG PJR KORLANTAS } \\
\text { POLRI }\end{array}$ & $\begin{array}{l}\text { Police Grand } \\
\text { Commissioner }\end{array}$ & Active \\
\hline KBP-03 & 52 & Male & $\begin{array}{c}\text { ANALIS KEBIJAKAN MADYA } \\
\text { SOPS POLRI }\end{array}$ & $\begin{array}{l}\text { Police Grand } \\
\text { Commissioner }\end{array}$ & Active \\
\hline KBP-04 & 52 & Male & $\begin{array}{c}\text { KABAGINFOPERS RO BINKAR } \\
\text { SSDM POLRI (PS) }\end{array}$ & $\begin{array}{l}\text { Police Grand } \\
\text { Commissioner }\end{array}$ & Active \\
\hline KBP-05 & 52 & Male & $\begin{array}{c}\text { ANALIS KEBIJAKAN MADYA } \\
\text { BIDANG NBC / INTERPOL }\end{array}$ & $\begin{array}{l}\text { Police Grand } \\
\text { Commissioner }\end{array}$ & Active \\
\hline $\begin{array}{c}\text { Informant } \\
\text { Code } \\
\end{array}$ & Age & Gender & Position & Rank & $\begin{array}{l}\text { Status } \\
\text { (Active / } \\
\text { Pension) }\end{array}$ \\
\hline & & & $\begin{array}{c}\text { DIVHUBINTER } \\
\text { SETNCBINTERPOLINDONESIA } \\
\end{array}$ & & \\
\hline KBP-06 & 56 & Female & $\begin{array}{l}\text { KABAGPRODIKLAT } \\
\text { BINDIKLAT } \\
\text { LEMDIKLAT POLRI } \\
\end{array}$ & $\begin{array}{l}\text { Police Grand } \\
\text { Commissioner }\end{array}$ & Active \\
\hline KBP-07 & 52 & Male & $\begin{array}{c}\text { ANALIS KEBIJAKAN MADYA } \\
\text { PUSDOKKES POLRI }\end{array}$ & $\begin{array}{l}\text { Police Grand } \\
\text { Commissioner }\end{array}$ & Active \\
\hline
\end{tabular}

(Source: Primary Data, 2019)

Qualitative research generally relies on self-reports, often in the form of indepth interviews, open ended interviews, or visual techniques (Yin, 2014), so the techniques and procedures used for data collection include: interviews, observation and documentation. This study uses a qualitative data analysis model of Miles and Huberman, which divides qualitative data analysis into three activities, namely: data reduction, data presentation, and drawing conclusions / verification (Sugiyono, 2014).

* Career Development of Indonesian National Police: The Case Study Analysis of Police Grand Comissioner Rank.

* $\quad$ https://doi.org/10.21009/JOBBE.003.2.04 


\section{RESULTS AND DISCUSSIONS}

\section{The Problem Case Analysis of Career Development of Grand Commissioner Po- lice in the Indonesian National Police}

The current police paradigm has changed its doctrine, becoming "friends partners and dependers of citizens", in the sense that the police are an inseparable part of society rather than the affairs of state power (Schlesinger, Nagi, \& Kremnitzer, 2017:77). In order to achieve the professionalism goals of the Indonesian National Police, human resources are needed as the main drivers in an organization. One of the development of human resources is career development. In the opinion of KBP-01 and KBP-02 informants:

"In the context of career development at the institution of the Indonesian National Police has a structured pattern through education and training and motivational measures for members." (KBP-01, 2019)

"... As for education and training (Diklat) located at the Indonesian National Police Education and Training Institution (Lemdiklat) is an Educational Institution under the Chief of Indonesian National Police in charge of organizing educational and training activities that function to form intelligent, skilled and qualified Indonesian National Police personnel in competence. "(KBP-02, 2019)

The purpose of conducting training organized by the National Police is to improve the ability and skills of personnel within the Indonesian National Police. Therefore the institution makes special regulations regarding the implementation of Indonesian National Police training as stipulated in Regulation Number 19 of 2010 concerning the Implementation of Indonesian National Police Training with the principles of legality, accountability, transparency, humanism, gradual, and continuing. Planning and new career development are policies in the form of direction of the top leadership to the management of human resources, especially the staffing section (Filstad \& Gottschalk, 2011:492).

According to Junjunan \& Suwanda (2019:104), these policies are then followed by practical steps that are administrative in nature: such as the issuance of an appointment decree, mutations in the form of promotion or demotion, job assignments or horizontal land transfers, pensions, etc. But with observant observations, basically the policies that apply from time to time are very visible certain patterns that lead to a career planning. As stated by informants KBP-03, KBP-04, and KBP-05:

... In developing career and career development, adequate and professional human resources are needed and there is a clear career pattern for Police Grand Commissioner personnel who hold positions both structural and functional, which in each position has its own characteristics and weights, so that stakeholders / prospective office holders, required to have certain qualifications according to their fields, think broadly, motivatively,

* Career Development of Indonesian National Police: The Case Study Analysis of Police Grand Comissioner Rank. 
able to work together, have good attitudes and behavior. "(KBP03, 2019)

"The importance of planned and targeted human resources" the right man on the right place "is undoubtedly a very urgent need, this is given the role of a Police Grand Commissioner as the backbone of the government in carrying out government tasks and implementation of development, then the development and utilization of these personnel become a very important part in improving performance. "(KBP-04, 2019)

"For the sake of ensuring future certainty and the quality of professional resources, it is necessary to develop employee career patterns so that employees can devote all their services in a calm and sincere manner. Career patterns are concrete forms and efforts to provide opportunities to develop their talents, interests, expertise, and experience in the position, based on the requirements that have been determined. "(KBP-05, 2019)

But on the other hand, there are several problems that occur related to the career development of Police Grand Commissioner personnel, including: 1.) Lack of regulations that support the implementation of police personnel programs; 2.) Lack of direction assistance from relevant agencies to support strategy implementation; 3.) Lack of budget and funding to run career development programs for Police Grand Commissioner personnel; 4.) There is no specific review related to the problems of occupation as a result of not absorbing the Police Commissioner personnel who have not held structural or functional positions and sometimes even not in accordance with their competence.

Regarding the problems in career planning for Police Grand Commissioner personnel, they also need to focus on psychological achievements which do not necessarily require promotion. Also explained by Dik, Sargent, \& Steger (2008:35) that there are two main elements of career planning, namely organizational career planning and individual career planning. Organizational career planning integrates human resource requirements and a number of career activities, focusing more on career paths. Individual career planning differs philosophically and procedurally from organizational career planning.

In other words, there are two different points of view related to career planning, that is, career planning can be centered on the organization, on individuals, or on both. There are four individual characteristics that influence how people make career choices according to Patrick \& Kumar (2011: 28), including: 1.) Career (People tend to pursue careers that are believed to be suitable to their interests); 2.) Identity (Career is an extension of one's identity, also as things that shape identity); 3.) Personality (This factor includes personal orientation and requires other individuals in terms of affiliation, power, and achievement needs); 4.) Social background (Socioeconomic status and the level of education and employment of parents in employees are factors that fall into this category.

From the description above, it states that individual and organizational careers are not separate and different. For this reason, organizations need to assist Police Grand Commissioner personnel in planning careers so that they can meet each other's needs. The career path is a flexible line of progressions through which Police Grand

* Career Development of Indonesian National Police: The Case Study Analysis of Police Grand Comissioner Rank.

* $\quad$ https://doi.org/10.21009/JOBBE.003.2.04 
Commissioner personnel move throughout their careers with an organization. Following career paths arranged to be able to develop careers with the help of organizations. Career development is a formal approach taken by organizations to ensure that people with the right qualifications and experience are available when needed.

\section{Problem Solving Identification of Career Development of Grand Commissioner Police in the Indonesian National Police}

The Grand Strategy of the Indonesian National Police 2005-2025 was prepared to be used as a guideline for all members of the National Police so that in carrying out their duties more directed, but in reality the performance of the National Police is still considered not in accordance with the expectations of the community, where the results of building trust (trust building) are not showing optimal results, even though The National Police has begun to face work programs in the form of partnership building. With this condition, it is certain that the challenges and workload of the Indonesian National Police in achieving strives for excellence will be increasingly severe.

This condition is in line with the process of regional autonomy which began since the enactment of Law Number 22 Year 1999 to Law Number 34 Year 2008, resulting in consequences for each region. Each region is demanded to be able to regulate and carry out its own government affairs in the hope that it will be able to improve the quality of public services in the context of regional development without dependence from the central government. The low quality of public services in the police is certainly closely related to the condition of human resources (Wilson, 2012:340).

Historically, there have been many attempts by the government to improve the quality of apparatus resources, for example through education education. Basically, there are three foundations underlying the discussion on the empowerment of the government apparatus, namely theoretical basis, pragmatic foundation, and normative foundation (Nurmadi, et. al., 2016:261). The theoretical foundation demands that regions look for innovations and tips as well as new breakthroughs so that the empowerment of the government apparatus can be optimized so that it can support the creation of efficient and fast public services. Pragmatic foundation requires regions to manage and utilize apparatus resources optimally. While the normative foundation requires regions to explore the potential of human resources in order to improve public services through a realistic and integrated policy. As stated by KBP-06 and KBP-07 informants:

"The importance of such education and training for Police Grand Commissioner personnel as human investment must be carried out. Development is not only intended to increase the effectiveness and efficiency of work, but also in order to accelerate the establishment of desired behavioral embodiments. "(KBP-06, 2019)

"In addition, no less important is through education and training, Police Grand Commissioner personnel are expected to be better adjusted or can anticipate various kinds of problems, needs and progress of the community, and fully realize the obligations in carrying out the tasks assigned to them. This condition is expected to improve the quality of public services for the better. "(KBP-07, 2019)

* Career Development of Indonesian National Police: The Case Study Analysis of Police Grand Comissioner Rank.

* $\quad$ https://doi.org/10.21009/JOBBE.003.2.04 
The function of the Police that carries out community security and order, law enforcement, protection, protection and service to the community is aimed at maintaining and maintaining the validity and obedience of the norms that exist in the community, so that life in society is safe, orderly, peaceful, peaceful and peaceful. prosperity (Kathimba \& Anyieni, 2018:164). If it is observed that the task of the police in any country is directed to the interests of the state or the government and the community, so that the state or government has the responsibility for maintaining, maintaining and maintaining public safety and order (Wilson \& Heinonen, 2012:304). In any country in the world, the people want to have a good police force, which means that in carrying out the functions of the police must be in accordance with the demands and needs of the community, so that the ideal police requirements are needed.

In forming an ideal police force and oriented to the needs of the community served there are several conditions and formulations that have been agreed upon by the world according to Jeffrey \& Soleman (2017:112), including: 1.) Well Motivated (meaning to get good quality police candidates for cadets the police must have good motivation when a police candidate chooses to become a police officer, this motivation will give a policing color to a police officer in developing his career, and this is monitored from the beginning of his recruitment); 2.) Well educated (meaning to get a good police candidate must be educated to be a good police officer which in this case touches on the education system, curriculum and teaching and learning process which is quite complex and complex); 3.) Well trainned (meaning to get a good police officer there needs to be training which goes through rigorous managerial processes so that synchronous education and training is able to answer various actual police challenges and challenges in the future); 4.) Well Equipment (this concerns the problem of police equipment which includes facilities and infrastructure as well as Police technology); 5.) Wellfare (i.e. reasonably adequate welfare of Police personnel).

Because the police in each country are confronted with different cultures, national ideologies and community characteristics, in addition to the five ideal police formulations, it is necessary to add especially those relating to police organization and supervision. Various development programs for police personnel have been implemented at Indonesian National Police. From the results of the previous analysis, it can be seen that the career development strategies of the Police Grand Commissioner personnel that have been implemented at Indonesian National Police include through various training, coaching and development, as well as rewards for outstanding personnel.

The results of the development of the Police Grand Commissioner personnel that have been implemented include the following: 1.) Through training programs, seminars and workshops an increase in work ability of the police personnel by mastering various skills and specific work implementation techniques; 2.) An increase in theoretical, conceptual and moral abilities that can be known from the results of the competency test; 3.) An increase in motivation and performance of police personnel as a result of the Police Grand Commissioner's guidance and career development program; 4.) Placement of positions in accordance with the competencies of the Police Grand Commissioner personnel.

\section{CONCLUSIONS}

This study concludes that career development is an police's efforts to achieve a career plan. These activities may be supported by the organization or not at all. However good a career plan that has been made by an employee is accompanied by a reasonable and realistic career goal, the plan will not become a reality without systematic

* Career Development of Indonesian National Police: The Case Study Analysis of Police Grand Comissioner Rank. 
and programmatic career development. This includes organizational efforts in the form of programs and activities to assist the career planning of Police Grand Commissioner personnel. It is hard to find a universal pattern about everyone's career because what happens is very diverse.

There are people who make progress in a career based on a particular career plan. But even without planning, there are people who make progress in their careers, so that progress is associated with "good fortune". Regardless of whether or not fate is linked to one's career, what is clear is that work performance, experience, training and development, in fact play an important role in taking various career paths of someone even within the institution of the Indonesian National Police. Another important thing is related to education and training provided to Police Grand Commissioner personnel must be in accordance with the requirements needed, so that the quality improvement of Police Grand Commissioner personnel will be truly fulfilled.

It is also based that the level of education and knowledge influences the choice of position obtained. The higher the level of education and the more extensive one's knowledge, the desire to do work with a high level of challenge is getting stronger. Education and training here is aimed at developing police competencies and careers in accordance with the needs and challenges of the performance of Police Grand Commissioner personnel.

\section{ACKNOWLEDGEMENT}

Praise for the presence of Almighty God, because of His blessing and blessing, the author is able to complete this research journal. Not to forget, the authors express their gratitude to the institution of Indonesian National Police, the Police Grand Commissioners who were informants in the research, and exclusive guidance from the Supervising Professors. Hopefully this article can bring benefits both practically and academically.

\section{REFERENCES}

Campbell, T. T. \& Armstrong, S. J. (2013). A longitudinal Study of Individual and Organizational Learning. The Learning Organization. Vol. 20 (3), pp. 240-256.

Dik, B. J., Sargent, A. M. \& Steger, M. F. (2008). Career Development Strivings: Assessing Goals and Motivation in Career Decision-Making and Planning. Journal of Career Development. Vol. 35 (1), pp. 23-41.

Filstad, C. \& Gottschalk, P. (2011). Becoming A Learning Organization: The Espoused Values of Police Managers from Two Norwegian Districts. The Learning Organization. Vol. 18 (6), pp. 486-500.

Griffin, R.W dan Moorhead, G. (2014). Organizational Behavior: Managing People and

Organizations (11 ${ }^{\text {th }}$ Ed.). United States of America: South-Western.

Gunawan, B., Lubis, R., Adam, M. \& Tabrani, M. (2016). The Effect of Human Resource Competency and Police Officer's Commitment on Career Development of Aceh Regional Police Officer. International Journal of Economics, Commerce, and Management. Vol. 6 (8), pp. 319-337.

Ivancevich, J. M., Konopaske, R. \& Matteson, M. T. (2013). Organizational Behavior and Management. Mc Graw-Hill Book Company.

Jeffrey, I. \& Soleman, M. (2017). The Effect of Work Discipline, Achievement Motivation, and Career Path Toward Employee Performance of the National Resil-

* Career Development of Indonesian National Police: The Case Study Analysis of Police Grand Comissioner Rank.

* $\quad$ https://doi.org/10.21009/JOBBE.003.2.04 
ience Institute of the Republic of Indonesia. International Journal of Application of Innovation Engineering

Management. Vol. 6 (8), pp. 106-114.

Junjunan, B. A. \& Suwanda, D. (2019). Integrated Career Patern Hope of Bureaucration in the Future. International Journal of Scientific \& Technology Research. Vol. 8 (5), pp. 96-107.

Kathimba, E. M. \& Anyieni, A. (2018). Effect of Workforce Diversity on Performance of National Police Service in Nakuru County, Kenya. International Academic Journal of Human Resource and Business Administration. Vol. 3 (1), pp. 150 $-169$.

Marnoch, G. Topping, J. \& Boyd, G. (2014). Explaining the Pattern of Growth in Strategic Actions Taken by Police Services During the New Labour Years: An Exploratory Study of an English Police Service. Policing and Society: An International Journal of Research and Policy. Vol. 24 (3), pp. 302-317.

Nurmadi, A., Muallidin, I., Suryanto. \& Priyopurnomo, E. (2016). The Indonesia's Police Reform Police in the Reform Era New Institutionalism Perspective. Journal of Government \& Politics. Vol. 7 (2), pp. 240-265.

Patrick, H. A. \& Kumar, A. (2011). Career Management, Employee Development and Performance in Indian Information Technology Organizations. Business Management Dynamics. Vol. 1 (5), pp. 24-31.

Prenzler, T. \& Sinclair, G. (2013). The Status of Women Police Officers: An International Review. International Journal of Law, Crime, and Justice. Vol. 41 (2), pp. 115-131.

Robinson, S. (2013). Promotional and Non-Stereotypical Policing Roles: Are Women Opting Out?. Salus Journal. Vol. 1 (3), pp. 1-12.

Sanders, B. A. (2003). Maybe There's No Such Thing As A "Good Cop": Organizational Challenges in Selecting Quality Officers. Policing: An International Journal of Police Strategies \& Management. Vol. 26 (2), pp. 313-328.

Schlesinger, T., Nagi, A. \& Kremnitzer, J. (2017). Competence Profile and Competence Training for the Police Service. SIAK: Journal for Police Science and Practice. Vol. 7 pp. 70-79.

Sethi, A. (2013). The $2^{\text {nd }}$ International Islamic Women Police Conference on Gender Responsive Policing: Building Synergies for Gender Reforms in Law Enforcement. Pakistan Journal of Crimonology. Vol. 5 (1), pp. 55-60.

Sugiyono. (2014). Metode Penelitian Kuantitatif, Kualitatif, dan Kombinasi (Mixed Methods).

Bandung : Alfabeta.

Trofymowych, D. (2007). Police Education Past and Present: Perceptions of Australian Police Managers and Academics. Flinders Journal of Law Reform. Vol. 8 (10), pp. 419-433.

White, M. D. (2008). Identifying Good Cops Early: Predicting Recruit Performance in the Academy. Police Quarterly. Vol. 11 (1), pp. 27-49.

White, M. D. \& Escobar, G. (2008). Making Good Cops in the Twenty-First Century: Emerging Issues for the Effective Recruitment, Selection and Training of Police in the United States and Abroad. Crime and Criminal Justice. Vol. 22 $(1 / 2)$, pp. 119-134.

Wibowo. (2015). Perilaku Dalam Organisasi (Ed. Ke-2). Jakarta: PT Raja Grafindo Persada.

Wilson, J. M. (2012). Articulating The Dynamic Police Staffing Challenge: An Examination of Supply and Demand. Policing: An International Journal of Police

* Career Development of Indonesian National Police: The Case Study Analysis of Police Grand Comissioner Rank.

* $\quad$ https://doi.org/10.21009/JOBBE.003.2.04 
Strategies \& Management. Vol. 35 (2), pp. 327-355.

Wilson, J. M. \& Heinonen, J. (2012). Police Workforce Structures: Cohorts, The Economy, And Organizational Performance. Police Quarterly. Vol. 15(3), pp. 283-307.

Wilson, J. M. (2014). Strategies for Police Recruitment: A Review of Trends, Contemporary Issues, and Existing Approaches. Law Enforcement Executive Forum. Vol. 14 (1), pp. 78-91.

Yin, R. K. (2014). Studi Kasus Desain \& Metode. Jakarta: Rajawali Pers.

* Career Development of Indonesian National Police: The Case Study Analysis of Police Grand Comissioner Rank.

* $\quad$ https://doi.org/10.21009/JOBBE.003.2.04 